Saqer Sulaiman

\title{
ARAB YOUTH MIGRATION TO THE EUROPEAN UNION
}

\author{
Arab fiatalok bevándorlása az Európai Unióba
}

Saqer Sulaiman, PhD candidate, University of Public Service, Doctoral School of Public Administration, Saqersul@yahoo.com

Migration from Arab countries to European countries started many decades ago. It has been driven by a variety of push-pull factors. The two main factors are economic deterioration and political instability. Many young people migrated to escape unemployment, poverty and poor working conditions. Others fled the effects of war and conflicts. This paper reviews Arab youth migration to European countries, its drivers, and the way it impacts the origin countries, host countries and the immigrants. Despite some negative implications of migration on the origin countries such as education cost and deprivation of the country from the potential capacity of skilled people, the benefits of these countries are rather clear and include remittances, knowledge and experience transfer. However, mitigation of Arab youth migration challenges is not an easy task; it needs new governmental approaches to reduce unemployment rates, as well as the active involvement of youth in economic and political life.

Keywords:

Arab countries, country of origin, host countries, migration, push-pull factors

Az arab országokból az európai országokba történő bevándorlás évtizedekkel ezelött kezdödött. A folyamatot különböző push és pull tényezők mozgatták, a két legfontosabb azonban a gazdasági visszaesés és a politikai instabilitás volt. Sok fiatal azért vándorolt ki, hogy elmeneküljön a munkanélküliségtöl, a szegénységtöl és a szerény munkafeltételektöl, mások a háború és a konfliktusok következményei elöl menekültek. Ez a tanulmány az arab fiatalok európai országokba irányuló migrációját, mozgatórugóit és hatásait tekinti át, figyelembe veszi továbbá a származási országokra, a befogadó országokra és a bevándorlókra gyakorolt hatásokat. A migrációnak a kibocsátó országokra olyan negatív következményei vannak, mint például az oktatási költségek, a képzett szakemberek esetleges kiesése a gazdasági életböl, azonban az elönyök is egyértelmüek: 
hazautalások, illetve a visszatérök ismereteinek és tapasztalatainak beépitése a helyi gazdaságba. Az arab fiatalok migrációs kihivásainak enyhitése nem könnyü feladat; új kormányzati megközelitésekre van szükség a munkanélküliségi ráta csökkentésének elérése érdekében, valamint szükséges a fiatalok aktív részvételének elömozditása a gazdasági és politikai életben is.

\section{KulCsSZAVAK:}

arab országok, kibocsátó ország, befogadó ország, migráció, push és pull tényezők 


\section{INTRODUCTION}

The migration of Arab youth to Europe represents a considerable phenomenon for discussion and study due to its impacts and patterns diversity, as it includes both less educated and highly-skilled migrants. In the past, the migration of Arab youth to Europe has often taken the form of legal migration, but, increasingly restrictive immigration regimes and border management in Europe, combined with high migration pressures in the Arab region and real labor market demands in Europe, have contributed to the rise in irregular migration'. 'The European Union is one of the main destinations for Arab migrants due to its geographical proximity, linguistic and historical ties: 'The central Mediterranean route has experienced the largest and fastest-growing flows with more than 170,000 arrivals in Italy alone in 2014, four times the number recorded in 2013. The number of departures has risen since the Arab spring in 2011.'2 Migration is one of the important aspects of the Arab-European relationship. As a point of fact, several initiatives and platforms have been stated to discuss migration issues and their implications for countries of origin and the host countries. These initiatives include the central Mediterranean contact group, Euromed migration projects and many others. The aim of these initiatives and meetings was to formulate common policies and to coordinate efforts on migration. This paper aims to review and analyse the migration of Arab youth to Europe and its impact on countries of origin, host countries and migrants themselves. The main data sources of this article are previous literature and international organisations' reports. This article seeks to answer the following questions: What are the magnitudes of youth migration from Arab countries to European countries? What are the drivers of Youth Migration from Arab countries? What are the impacts of this migration on both Arab countries and the host countries? In essence, the article strives to address the aforementioned research questions by applying one main hypothesis which dictates that the migration of Arab youth is driven by specific push and pull factors in both the home country and the host country, and the impacts extend to both countries and immigrants, as well.

\section{THE MAGNITUDE OF ARAB YOUTH MIGRATION TO EUROPEAN COUNTRIES}

Migration is a global phenomenon, it is not limited to a certain region or country, but it spans all over the world: 'In 2013, young international migration aged 15-24 represented 12.2 percent (i.e. an estimated number of more than 28 million individuals) of all

ESCWA and IOM, Migration, Displacement and Development in a Changing Arab Region, situation report on international migration (Beirut, 2015), 20.

Ibid. 
international migrants worldwide. ${ }^{3}$ However, emigration and displacement from Arab countries are well-evident. For example, 'the number of migrants and refugees originating from the Arab region has grown from approximately 11.5 million in 1990 to 29 million in 2017, increasing by 153 percent in the 27 years' ${ }^{4}$ It is also worth mentioning that 'the number of Arab migrants was 24 million in 2015, and they account for $10 \%$ of the international migrants stock'. ${ }^{5}$ Notably, data show that the phenomenon of youth migration has increased dramatically in the last decade. A survey conducted by the Arab Center for Research and Policy Studies (2020) revealed that ' $22 \%$ of the respondents want to immigrate, and the majority of them want to do so in order to improve their economic situation. However, about $15 \%$ said that their motive is education, and $12 \%$ want to emigrate for political or security reasons'. ${ }^{6}$ In terms of the destinations of Arab youth migration, the survey carried out by the Arab Center for Research and Policy Studies (2016) shows that 'the majority of the respondents (37\%) want to migrate to Europe, while $20 \%$ prefer the Arab Gulf States, $12 \%$ to the USA, and $9 \%$ to Canada, however, the rest is distributed to countries such as Turkey, African countries, and others'?

Along the same line, 'immigrants from Algeria, Egypt, Jordan, Lebanon, Libya, Morocco, Palestine, Tunisia, and Western Sahara) around the world are mostly concentrated in the EU, of which France (with 2,828,623) has the greatest share, followed by Spain and Italy'. ${ }^{8}$ Obviously, in addition to the other Arab countries such as the Gulf States, and some Asian countries like Turkey, Europe stands as another destination for Arab migrants and displaced persons. Accordingly, 'over $40.4 \%$ of Arab migrants went to OECD countries, especially European Union countries'.

\section{DRIVERS OF ARAB YOUTH MIGRATION}

A combination of push-pull factors usually leads to the decision to migrate. Historically speaking, the Arab youth migration has been driven by a variety of factors on top of which are economic reasons, violence and insecurity, and lack of human rights enforcement. In general, the economic situation in many Arab countries is distinguished by the fact that it is still suffering because of the instability and geopolitical influence in the region.

3 ILO, Youth Employment and Migration: A review for practices from joint programs of the United Nations/ International Labour Office, Employment policy Department, Youth Employment Program (Geneva, 2013), 36.

4 ESCWA and IOM, Situation report on international migration 2019: The global compact for safe, orderly, and regular migration in the context of Arab region (Beirut, 2019), 25.

IOM, Migration to, from and in the Middle East and North Africa (Geneva, 2016), 4.

6 Arab Center for Research and Policy Studies, The 2019-20 Arab Opinion Index: Main Results in Brief (Doha, 2020), 6.

Arab Center for Research and Policy Studies, Arab Indicator (Doha, 2016), 42.

8 Elena Sánchez-Montijano and Marina Girona-Raventós, 'Arab Mediterranean Youth Migration: Who Wants to Leave, and Why?' EuroMesco Policy Brief 73 (2017), 3.

9 League of Arab States, Regional Report about Arab International Migration, International Migration and Development (Cairo: League of Arab States publishing, 2014), 9. 
One of the main challenges facing many Arab countries is the steady increase in public debt whereby 'the total public debt of Arab countries increased from USD 665.9 billion in 2017 to about USD 707.8 billion in 2018'. ${ }^{10}$ This debt constitutes a burden on many Arab countries and impedes development trends, which makes migration an inevitable decision for Arab youth. The considerably high unemployment rate is another important indicator of the economic situation in Arab countries. The inability of the labour market to absorb the growing numbers of graduates is one of the main push factors in Arab countries. As for unemployment, it is one of the highest in the world, especially in countries such as Palestine, Syria and Yemen. The average rate of unemployment in Arab countries was ' $10.0 \%$ in 2018 , almost double the world average, disproportionately affects young people, at 25 percent'. ${ }^{11}$ It is also interesting to mention that the Arab youth were the most affected by the bad economic situation in the Arab countries. Furthermore, the economic condition is the major reason that led Arab experts and highly educated individuals to leave their homeland especially when they find themselves receiving an income lower than those who are not educated or who do not have the same level of education. Despite some fluctuation in the unemployment rate in the Middle East and North Africa from year to year, there was 'a significant increase in the unemployment rate among youth after 2011', ${ }^{2}$ because of political and social crises in the Arab countries. The relationship between the increase in the unemployment rate and political instability is well clear. In Syria for example, 'the unemployment rates increased from almost 15 percent in 2011, prior to the civil war, to 57.7 by the end of $2014 \cdot{ }^{13}$ Regarding the effect of the Arab spring on migration among youth, some studies argued that 'the uprisings in countries like Tunisia and Egypt fuelled irregular emigration to the EU. Some European countries recorded an increase in Tunisian, Egyptian and Moroccan immigrants in the 2010-2013 periods, noticeably Italy. ${ }^{14}$

Although, economic factors are considered the most important driving force of migration, 'the decision to migrate also may be driven more by broader career concerns such as the quality of opportunities to conduct research, to gain experience, upgrade qualifications, safer environment, as well as a lifestyle, ${ }^{15}$ than by how much more individuals could earn abroad. While among highly skilled people, 'salary discrepancies and differences in working conditions make the greatest difference. ${ }^{16}$ Corruption, and nepotism which are common survival strategies in Arab countries, negatively influence all areas of life. 'One of

10 Arab Monetary Fund, The Joint Arab Economic Report: Overview and Statistical Annexes (Arab Monetary Fund, Economic Department, 2019), 12.

11 United Nations Development Program, Arab Human Development Report: Leaving No One Behind (New York: United Nations, 2019), 23.

12 ILO, Global Employment Trends: Preventing a deeper jobs crisis (Geneva, 2012), 93.

13 UNDP and RBAS, Arab Human Development Report: Youth and the Prospects for Human Development in a Changing Reality (New York: United Nations, 2016), 139.

14 Sánchez-Montijano and Girona-Raventós, 'Arab Mediterranean Youth Migration', 4.

15 Michael Clemens, Skill Flow: A Fundamental Reconsideration of Skilled-worker Mobility and Development (Washington, D.C.: Center for Global Development, 2009), 12.

16 IOM, World Migration Report: An Overview of International Migration (Geneva, 2003), 221. 
the imbalances in developing societies is the prevalence of mismanagement, favoritism, not putting the right person in the right place, and incompatibility of income with production. ${ }^{17}$ However, the weakness of the legislative and judicial authorities compared to the executive authority is one of the main causes of corruption in the Arab region. According to the Corruption Perception Index (2019), 'the rates of all Arab countries were below 50, except for the United Arab Emirates, Qatar, Saudi Arabia, and Oman..18 Moreover, 'human rights in most of the Arab countries is a major challenge, particularly the right of highly educated people in making their decisions and exercising their general freedoms ${ }^{19}$ as many highly educated individuals fled not because they could not find a job, but because they did not wish to live in such a socio-political environment. On the other hand, developed countries can provide migrants with better opportunities for work and scientific research in addition to another main pull factor of migration: better individual well-being and social security services in receiving countries compared to Arab countries. Conflicts and political instability is another factor that drives Arab youth migration. Indeed, many Arab countries are still suffering from the continuity of political conflicts. In Syria, Lybia and Yemen, for example, there is no political solution looming so far. Furthermore, Palestine is still a country under occupation, wherein the violation of human rights has been apparently due to the Israeli restrictions. Undoubtedly, occupation measures are a major factor that encourages the youth to migrate to avoid such an unfavorable socio-political environment.

However, it is equally important to mention that there is a relationship between geographical location and colonial relations between sending countries and receiving countries. According to the gravity model, migrants' flows to host countries are affected by a set of variables including natural and artificial factors. 'Natural factors include distance, transport, information, and psychic costs. Whilst, artificial factors include government limitations on freedom of travel and population movements. ${ }^{20}$ Thus gravity model relies on data on origin-destination migration flow, demographic factors, population and distance. Therefore, the volume of migration between any two interacting centres is the function of two main factors, the distance between them and the population size. Indeed, this model explains to some extent the migration of Arab youth to Europe, and how the demographic factor and the geographical dimension affect the patterns and trends of this migration. To conclude, in general terms, push-pull factors can include a wide range of circumstances at internal and external levels. These factors may include socio-economic conditions of various kinds when people are looking to move from places or countries where they are less likely to get employment or seeking opportunities to go to other destinations where they may be more fortunate.

Ahmad Al-Ali Darda, Arab Brain Drain: Causes and Ways of Remedy (Beirut: Al-Manra, 2003), 26.

Transparency International, Corruption Perception Index 2019 (Berlin: Transparency International, 2020), 18.

Attouf, M Y, Brain Drain: The Emigration of Arab Talent to Developed Countries (Beirut: Dar Al-Andalus, 1984), 49.

20 David Karemera et al., 'A gravity model analysis of international migration to North America', Applied Economics 32, no 13 (2000), 1747. 


\section{IMPLICATIONS OF ARAB YOUTH MIGRATION}

The impacts of migration are various; they affect destination countries and origin countries. Both parties are gaining benefits and suffer losses. 'The countries of immigration obtain growth of the economy, increased competition in the labor market, more taxpayers, and cheap foreign labor; while countries of emigration obtain remittances, decrease in a rate of employment and free labor training. ${ }^{21}$ In the following sections, the author will review the main benefits and losses of the origin countries, the host countries and the immigrants.

\subsection{The implications of migration on the countries of origin}

Most Arab countries view migration as an inevitable solution to unemployment. ${ }^{22}$ As such, many Arab governments contracted bilateral agreements with some other countries to organise and regulate Arab labour migration to these countries. Additionally, Arab countries have worked through the League of Arab States to establish mechanisms of cooperation and partnership with other regions and groups, such as 'the African-Arab summit, the summit of American-Arab countries, and the European Union Arab league foreign affairs ministerial meetings'. ${ }^{23}$ The effects of migration on development and well-being in Arab countries are still the subject of debate among researchers as it entails benefits and losses for these countries. One negative implication of the Arab youth migration is the depletion of highly educated human resources from the MENA region. Generally speaking, Arab countries are suffering from the loss of their newly qualified medical doctors, engineers and scientists each year, many of them move to the European Union, the United States and Canada. According to the Arab League and the Arab Labour Organization statistics, 'the Arab world takes up about $31 \%$ of the brain drain from developing countries; about $50 \%$ of doctors, $23 \%$ of engineers and $15 \%$ of the scientists of the total Arab talent migrated to Europe and the United States and Canada'. ${ }^{24}$ For example, in 'the United Kingdom the percentage of Arab doctors of the total physicians working there is 34\%. ${ }^{25}$ At the same time, 'the number of highly-skilled-born Arab residents in the OECD countries, particularly the European Union, was more than one million; about half of them came from the Arab Maghreb countries'. ${ }^{26}$

These statistics and data indicate the extent of the losses incurred by the Arab states as a result of youth migration, especially highly skilled migrants. The losses involve not only

21 Yuriy Kozak and Temur Shengelia, International Economic Relations (Tbilisi: Universal, 2014), 97-98.

22 Farris Albeel, Energy drain. Paper presented at the Youth Immigration Seminar (Tunisia, 2012), 9.

23 Enas El-Fergany, 'Regional cooperation in international migration: The case of the Arab Region', The Journal of Migration Policy Practice 5, no 3 (2015), 7.

24 Ibrahim Qwaider, The loss of talent for the benefit of other countries, to stop Arab brain drain, 2004, 6.

25 Aida Ezzat, Arab Brain Drain (Egyptian Ministry of Industry and Foreign Trade, 2008), 6.

26 Myson Fogo, Human Development Strategies and their Role in Alleviating the Scientific Brain Drain Phenomenon in Palestine (Gaza: The Islamic University, 2012), 32. 
the financial cost of education and training of Arab emigrant's youth, but it includes also losses of minds and skills that could otherwise contribute to the development processes in these countries. On the other hand, most Arab countries have dealt with migration as a solution to economic and social challenges such as unemployment and poverty. As such remittances have been viewed by the Arab Government as one of the revenues of the Arab economy. Remittances represent one of the main benefits received by the Arab countries. It covers the expenses of household, healthcare and may create incentives for more investment in academic education and vocational training. Actually, 'the ratio of remittances to the GDP in the Arab region was 2.2\%' ${ }^{27}$ Figure 1 shows the remittances inflows and the ratio of remittances to the GDP in some Arab countries in 2017.

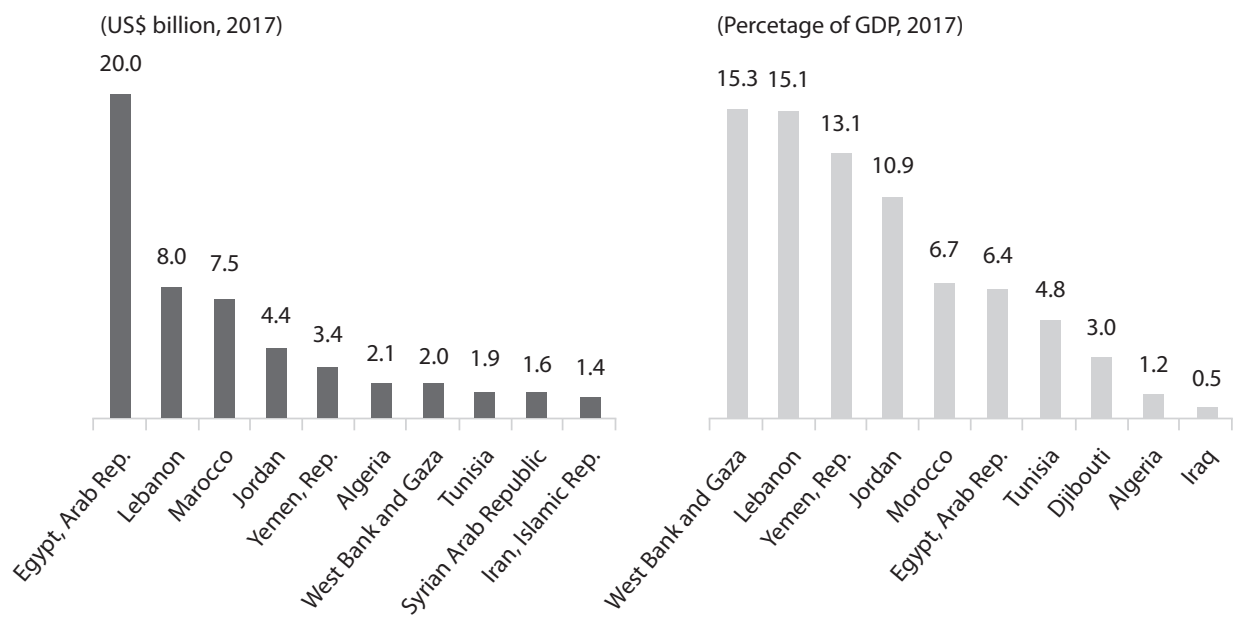

Figure 1 - Remittances inflow and the ratio of remittances to GDP in some Arab countries 2017 (Source: World Bank Group, 2018, 31.)

The figure above shows that Egypt was the largest recipient of remittances in the Middle East and North Africa region in 2017 (\$20 billion), followed by Lebanon (\$8 billion) and Morocco ( $\$ 7.5$ billion). While Palestine (West Bank and the Gaza Strip) was the highest in terms of remittances to GDP percentage (15.3 per cent) followed by Lebanon (15.1 per cent) and Yemen (13.1 per cent). However, it is interesting to note that in Arab countries, remittances are generally used to cover the cost of household expenses and healthcare. This means that remittances correlate more closely with private consumption than with investment purposes in the Arab context. Table 1 shows the purposes of spending in some Arab countries.

27 League of Arab States, Regional Report about Arab International Migration, 34. 
Table 1 - The purposes of spending remittances in some Arab countries, \% (Source: League of Arab States, 2014. (28 $^{28}$

\begin{tabular}{|l|c|c|c|c|c|c|}
\hline \multicolumn{1}{|c|}{ Country } & $\begin{array}{c}\text { Daily } \\
\text { expenditure }\end{array}$ & $\begin{array}{c}\text { Educational } \\
\text { expenses }\end{array}$ & $\begin{array}{c}\text { Building } \\
\text { a house }\end{array}$ & $\begin{array}{c}\text { Establishment } \\
\text { of a company }\end{array}$ & Investments & Other \\
\hline Algeria & 45 & 13 & 23 & 3 & 5 & 11 \\
\hline Egypt & 43 & 12 & 18 & 0 & 15 & 12 \\
\hline Jordan & 74 & 16 & 4 & 0 & 6 & 0 \\
\hline Lebanon & 46 & 24 & 5 & 08 & 5 & 5 \\
\hline Morocco & 56 & 31 & 16 & 0 & 5 & 2 \\
\hline Tunisia & 0 & 23 & 34 & 2 & 16 & 25 \\
\hline Syria & 61 & 11 & 8 & 0 & 0 & 20 \\
\hline
\end{tabular}

As the above table shows, among the Arab countries, the best country in utilising and investing these remittances is Tunisia (16 per cent) followed by Egypt (15 per cent), while this ratio was only 5 per cent in Algeria, Morocco and Lebanon, and 0 in Syria due to the permanence of conflict and political instability.

\subsection{The implications of migration on the host countries}

Managing migratory issues with the MENA region is one of the main components of the agenda of the European Union. The EU has promoted initiatives and agreements with some Arab countries on different levels. These initiatives include, but are not limited to 'regional dialogues like the Khartoum Process in 2014, bilateral dialogues on migration, mobility and security with Morocco and Tunisia in 2011, and more recently with Lebanon in 2014 and important bilateral agreements, such as the two Mobility Partnerships signed with Morocco in 2011 and with Tunisia in 2014' ${ }^{29}$ The aims of these various approaches and initiatives are to foster cooperation on migratory issues, mitigate the negative impacts of migration, and make it less permanent and more mutually beneficial. The Barcelona Process which was launched in 1995 with the aim of strengthening the Mediterranean partnership primarily tackles three principles: the reduction of migratory pressures through job creation; the fight against illegal migration; and the protection of the rights of legal migrants. ${ }^{30}$ The continuity of Arab youth migration to other host countries such as European countries brings both benefits and losses to the host countries as well as to the immigrant himself. Utilising cheap migrant labour, the host countries decrease the cost of production and increase the competitiveness of their products in the international labour

\footnotetext{
28 The information is collected and translated from the original Table 3.1, 137.

29 Sánchez-Montijano and Girona-Raventós, 'Arab Mediterranean Youth Migration', 4-5.

30 European Commission, Barcelona Declaration. Adopted at the Euro-Mediterranean Conference, 27-28 November 1995.
} 
market. Moreover, 'the host country wins at the expense of the taxes which size depends on qualifying and age structure of immigrants' ${ }^{31}$

Although European Union institutions have recognised the benefits of realistic and proactive migration policies, they also know that these will only be successful if coupled with the socio-economic, civic and political inclusion of migrants. ${ }^{32}$ The integration of Arabs into European societies is one of the most important challenges for the European Union. Overcoming the disagreement between the need for highly skilled young immigrants and low-cost labour to maximise profit from migration and the fear of losing the distinct identity and the diversity of the culture and values is one of the main challenges the European governments have to face. It is not easy to provide a clear depiction of the reality of the integration of Arab youth into European societies, due to the difference in the policies of European countries towards the integration process. For example, from the European point of view, the integration is based on the immigrant's acceptance of European laws, principles, norms and values. ${ }^{33}$ On the other hand, 'from Islamic and Arab perspectives, this process should depend on the inclusion of immigrants into European societies on the basis of citizenship and social \& political contract'. ${ }^{34}$ Integration is not an easy process, it needs reciprocal cooperation from all sides, and it should be developed gradually and continuously in order to be succeeded. Actually, integration is a two-way process; 'it requires adaptation on the part of the newcomer but also successful integration can only take place if the host society provides access to jobs and services, and acceptance of the immigrants in social interaction'. ${ }^{35}$

\subsection{The impact of migration on Arab youth immigrants}

Living in western societies allowed Arab youth to benefit from the different characteristics of those societies, as well as trying their best to adapt to the western lifestyle of western countries. For example, many Arab youth residing in western countries choose to marry a western citizen of those countries and start a family, which facilitates their interactions with the new social context and broadens their integration into the host societies. Integration in terms of work, language, and gaining the values and cultures of societies is crucial to the success of immigrants in their new lives. With regards to the impact on skills and knowledge of Arab youth immigrants, it is not surprising that immigration to developed

$31 \quad$ Kozak and Shengelia, International Economic Relations, 98.

32 Anja Rudiger and Sarah Spencer, The Economic and Social Aspects of Migration: Social Integration of Migrants and Ethnic Minorities. Conference Jointly Organised by the European Commission and the OECD, Brussels, 21-22 January 2003.

33 Christian Joppke, 'Beyond National Models. Civic Integration Policies for Immigrants in Western Europe', West European Politics 30, no 1 (2007), 3.

34 Ali Awad, Integration of Muslims in European Societies through Two Visions, 2014.

35 Stephen Castles et al., Integration: Mapping the Field. Report of a Project carried out by the University of Oxford, 2002, 113. 
and scientifically advanced countries increases access to opportunities that will subsequently benefit immigrants and the country of origin. Undoubtedly, 'the migrant who gets the opportunity to work in the same area of his or her educational qualification and training is more likely to engage with knowledge transfer or development programs back home. ${ }^{36}$

The training and experience Arab youth immigrants receive and gain in their host countries are greatly superior to what they can do for their countries of origin in case they choose to return home. It is important to note that the acquisition of skills and experience is less likely to occur in the absence of an incubator that provides individuals with opportunities to work and practice in areas that allow them to utilise what they have learned. Hence, it is very important to integrate immigrants, especially in learning the language of the host country, in order to facilitate their access to more opportunities.

Nevertheless, the idea of immigration remains a difficult decision, as it involves some difficulties and is fraught with uncertainty and risks. The Arab youth who choose the so-called irregular immigration put their lives at risk, as this type of migration is facilitated and organised by networks of smugglers who often use high-risk routes. The International Organization for Migration recorded '5,098 deaths by people making Mediterranean crossing in 2016 on top of the 3,784 people reported dead or missing in 2015. Between 1 January 2017 and 6 March 2017 there are further 521 recorded deaths'. ${ }^{37}$ In addition, finding a job in the host country is not a flower-paved road. The jobs that young migrants may get or be offered, depend mainly on his/her skills and educational qualification, sometimes the immigrants' endeavours to find jobs that commensurate with their skills are not an easy task. Furthermore, data revealed that immigrants are still among the least fortunate groups in host communities. 'Migrants are often the first to lose their jobs in the event of an economic downturn. Some work for less pay, and in worse conditions than native-born workers. Some migrants endure human rights violations, abuse, and discrimination. ${ }^{38}$ Nevertheless, in order to reduce the risks and costs of migrations, 'most youth migrants prefer to move to areas where members of their network already reside'. ${ }^{39}$

To sum up, the disparity in the political and economic environments between the MENA region and Europe, including the distribution of capital and labour, pushes Arab youth to migrate from Arab countries to European countries. Interestingly, the impacts of youth migration affect both the home country and the host country; in addition to the benefits gained by migrants. Despite the adverse impacts of Arab human migration, it has had a reasonable impact on the Arab countries, where benefits include sending remittances and transferring knowledge and best practices to their home country. On the other hand,

36 Sheila Siar, 'Diaspora Knowledge Transfer as a Development Strategy for Capturing the Gains of Skilled Migration', Asian and Pacific Migration Journal 23, no 3 (2014), 307.

37 Andrew Geddes and Leila Hadj-Abdou, 'Changing the Path? EU Migration Governance after the 'Arab Spring," Mediterranean Politics 23, no 1 (2018), 143.

38 United Nations, International Migration Report (New York: Department of Economic and Social Affairs, 2017 ), 1.

39 United Nations, World Youth Report: Youth and Migration (New York: United Nations, Department of Economic and Social Affairs, 2013), 25. 
host countries get cheap labour and highly skilled immigrants who can contribute to the development and scientific research in these countries. Certainly, immigrants can also reap benefits from their mobility to other countries, such as financial returns and the acquisition of skills and experience.

\section{CONCLUSION}

Migration is an international phenomenon that affects mostly developing countries, including the Arab countries. The accumulation of capital and opportunities in developed and more developed countries accelerate the movement of the labour of particularly educated youth to these countries; as a result, the Arab countries become vulnerable to the depletion of highly educated people. Migration from the Arab countries continued because of the effect of several factors. These factors include, but are not limited to, economic stagnation, unemployment, corruption and favoritism, and political instability. Estimates indicate that the increase in the unemployment rate over time and the continuing gap between the population growth rates and economic growth will increase the expulsion factors, and push additional numbers of Arab labour to migrate. Concerning the sociopolitical context, the political conflicts and civil war are still afflicting many Arab countries such as Syria, Lybia and Yemen. This created difficult economic and living conditions in these countries and contributed to raising the levels of emigration among Arab youth from these unstable countries. The main detrimental effect of immigration was the loss of scientists and experts resulting in a permanent need for skills especially in certain fields such as medicine and physics.

Despite the negative effects of youth emigration from the Arab countries, because of the loss of scientists and experts, Arab countries also benefitted from migration. Remittances are one of the main benefits, but unfortunately, most of them are used for personal consumption instead of investment or entrepreneurial projects. The redirection of remittances towards investment rather than consumption is likely to contribute to improving the labour market in Arab countries; this will positively affect the welfare of the citizen. The Arab governments, therefore, must adopt creative policies to maintain their pool of young talent and decrease the rate of migration of youth and highly skilled people. From a development point of view, strengthening the relationship with Diasporas and supporting their initiatives towards their home countries is a key policy that must be adopted by the Arab governments. These initiatives may include economic investments and knowledge transfer. Finally, improving the Arab institutions' potentials to absorb and utilise the experiences of repatriates and highly skilled migrants necessitates the creation of evidence-based policies; and also the improvement of the level of coordination and cooperation between migration-associated institutions. 


\section{REFERENCES}

1. Albeel, Farris, Energy drain. Paper presented at the Youth Immigration Seminar. Tunisia, 2012. Translated from Arabic.

2. Awad, Ali, Integration of Muslims in European Societies through Two Visions, 2014. http://blog.marefa.org/?q=node/1209 (accessed 03 June 2019).

3. Arab Center for Research and Policy Studies, Arab Indicator. Doha, 2016.

4. Arab Center for Research and Policy Studies, The 2019-20 Arab Opinion Index: Main Results in Brief. Doha, 2020.

5. Arab Monetary Fund, The Joint Arab Economic Report: Overview and Statistical Annexes. Arab Monetary Fund, Economic Department, 2019.

6. Attouf, M Y, Brain Drain: The Emigration of Arab Talent to Developed Countries. Beirut: Dar Al-Andalus, 1984. Translated from Arabic.

7. Castles, Stephen, Maja Korac, Ellie Vasta and Steven Vertovec, Integration: Mapping the Field. Report of a Project carried out by the University of Oxford, 2002.

8. Clemens, Michael, Skill Flow: A Fundamental Reconsideration of Skilled-worker Mobility and Development. Washington, D.C.: Center for Global Development, 2009. DOI: $10.2139 /$ ssrn.1477129

9. Darda, Ahmad Al-Ali, Arab Brain Drain: Causes and Ways of Remedy. Beirut: Al-Manra, 2003.

10. Economic and Social Commission for Western Asia (ESCWA) and International Organization for Migration (IOM), Migration, Displacement and Development in a Changing Arab Region, situation report on international migration. Beirut, 2015.

11. Economic and Social Commission for Western Asia (ESCWA) and International Organization for Migration (IOM), Situation report on international migration 2019: The global compact for safe, orderly, and regular migration in the context of Arab region. Beirut, 2019.

12. El-Fergany, Enas, 'Regional cooperation in international migration: The case of the Arab Region'. The Journal of Migration Policy Practice 5, no 3 (2015), 3-8.

13. European Commission: Barcelona Declaration. Adopted at the Euro-Mediterranean Conference, 27-28 November 1995. https://ec.europa.eu/research/iscp/pdf/policy/barcelona_declaration.pdf (accessed 05 August 2019).

14. Ezzat, Aida, Arab Brain Drain. Egyptian Ministry of Industry and Foreign Trade, 2008. www.mfti.gov.eg/SME/pdf/researchs/8.pdf (accessed 14 February 2019).

15. Fogo, Myson, Human Development Strategies and their Role in Alleviating the Scientific Brain Drain Phenomenon in Palestine. Thesis presented for Master Degree in Business Management. Gaza: The Islamic University, 2012.

16. Geddes, Andrew and Leila Hadj-Abdou, 'Changing the Path? EU Migration Governance after the 'Arab Spring'.' Mediterranean Politics 23, no 1 (2018), 142-160. DOI: 10.1080/13629395.2017.1358904

17. International Labour Organization (ILO), Global Employment Trends: Preventing a deeper jobs crisis. Geneva, 2012. 
18. International Labour Organization (ILO), Youth Employment and Migration: A review for practices from joint programs of the United Nations. International Labour Office, Employment Policy Department, Youth Employment Program, Geneva, 2013.

19. International Organization for Migration (IOM), World Migration Report: An Overview of International Migration. Geneva, 2003.

20. International Organization for Migration (IOM), Migration to, from and in the Middle East and North Africa. Geneva, 2016.

21. Joppke, Christian, 'Beyond National Models: Civic Integration Policies for Immigrants in Western Europe'. West European Politics 30, no 1 (2007), 1-22. DOI: 10.1080/01402380601019613

22. Karemera, David, Victor Iwuagwu Oguledo and Bobby Davis, 'A gravity model analysis of international migration to North America'. Applied Economics 32, no 13 (2000), 1745-1755. DOI: 10.1080/000368400421093

23. Kozak, Yuriy and Temur Shengelia, International Economic Relations. Tbilisi: Universal, 2014.

24. League of Arab States, Regional Report about Arab International Migration, International Migration and Development. Cairo: League of Arab States publishing, 2014. Translated from Arabic.

25. Qwaider, Ibrahim, The loss of talent for the benefit of other countries, to stop Arab brain drain, 2004. www.3rbe4ever.hooxs.com/t6507-topic (accessed 04 December 2018). Translated from Arabic.

26. Rudiger, Anja, and Sarah Spencer, The Economic and Social Aspects of Migration: Social Integration of Migrants and Ethnic Minorities. Conference Jointly Organised by the European Commission and the OECD, Brussels, 21-22 January 2003. www.oecd. org/migration/mig/15516956.pdf (accessed 08 November 2019).

27. Sánchez-Montijano, Elena and Marina Girona-Raventós, 'Arab Mediterranean Youth Migration: Who Wants to Leave, and Why?' EuroMesco Policy Brief 73 (2017), 1-14.

28. Siar, Sheila, 'Diaspora Knowledge Transfer as a Development Strategy for Capturing the Gains of Skilled Migration'. Asian and Pacific Migration Journal 23, no 3 (2014), 299-323. DOI: 10.1177/011719681402300303

29. Transparency International, Corruption Perception Index 2019. Berlin: Transparency International, 2020. www.transparency.org/files/content/pages/2019_CPI_Report_ EN.pdf (accessed 30 August 2020).

30. United Nations, World Youth Report: Youth and Migration. New York: United Nations, Department of Economic and Social Affairs, 2013.

31. United Nations, International Migration Report. New York: Department of Economic and Social Affairs, 2017.

32. United Nations Development Program, Arab Human Development Report: Leaving No One Behind. New York: United Nations, 2019. 
33. United Nations Development Program (UNDP) and Regional Bureau for the Arab States (RBAS), Arab Human Development Report: Youth and the Prospects for Human Development in a Changing Reality. New York: United Nations, 2016.

34. World Bank Group, Migration and Remittances: Recent Developments and Outlook. Migration and Development Brief No. 29. Washington, D.C.: World Bank, 2018. 
Saqer Sulaiman is a $\mathrm{PhD}$ candidate, graduated from Al-Quds University and has a master degree in human development and institutional building. After serving as the director of the Development and Projects Department in the Ministry of the Interior in the Palestinian National Authority (PNA), he is currently associated as the Director of Expatriates and Migration Department in the PNA. He also served as a national focal point for the Euromed migration project in Palestine. He has several publications including network governance of migration profile in Palestine, knowledge management of the Palestinian National Authority Institutions, public administration in Palestine, brain drain in the Arab countries and risk management in Palestinian institutions. 